Marcin Poprawski (i) http://orcid.org/0000-0002-2566-3500

Instytut Kulturoznawstwa, Uniwersytet im. Adama Mickiewicza w Poznaniu e-mail: poprawski@amu.edu.pl

Otrzymano/Received: 30.03.2021

Zaakceptowano/Accepted: 1.09 .2021

Opublikowano/Published: 30.09.2021

\title{
Nowe siedziby instytucji kultury w Polsce - perspektywa lokalnych ekosystemów kultury
}

\author{
Abstract \\ New Venues of Cultural Institutions in Poland - the Perspective of \\ Local Cultural Ecosystems
}

Building new venues for cultural activity involves a shift in the balance of power in the entire system of relations in the local communities of authors and organisers. This is a matter of budget and, very often, also of cultural policy priorities. Furthermore, it entails a significant change in the longterm funding of cultural initiatives and cultural entities in each region. The phenomenon of the emergence of many new cultural facilities has inspired a few fundamental questions about their attitudes to selected values in the field of sustainable development goals, particularly in the social and economic dimensions, but ultimately also of the impact of new cultural venues on the natural environment. Are the new investments in culture opportunities, challenges, or perhaps threats resulting from the rescaled or disturbed balance in local cultural ecosystems? The theoretical perspective, which organises the debate on these areas, takes the cultural ecosystem as a key concept, using it as a basis for the description of phenomena in local urban communities. The observations presented are based on the qualitative and quantitative research conducted in eight cultural institutions in eight Polish cities. The results reveal the importance of between ten and twenty fundamental dimensions of the activity of cultural institutions and their local government organisers which allow them to put down their roots more deeply in the city's cultural ecosystem. A new building opens completely new possibilities, but it is extremely important to tailor the institution to the real, sagaciously assessed, and well-balanced possibilities of the local ecosystem.

Keywords: local cultural ecosystems, cultural institutions, cultural infrastructure, sustainable development 
Słowa kluczowe: lokalny ekosystem kultury, instytucje kultury, infrastruktura kulturalna, zrównoważony rozwój

\section{Wprowadzenie}

Nowe budynki obiektów koncertowych, centrów kultury, teatrów, muzeów lub bibliotek zwiększają dla publiczności dostępność działań czy zbiorów, zapewniają lepsze warunki osobom pracującym w instytucji, skuteczniej zabezpieczają obiekty dziedzictwa kulturowego. Ale budowanie nowych miejsc dla aktywności kulturalnej to również zmiana układu sił w całym systemie relacji w lokalnych środowiskach twórców i organizatorów. To wymiar budżetowy i równie często sprawa priorytetów polityki kulturalnej, a także znacząca zmiana w wieloletnim finansowaniu inicjatyw i podmiotów kulturalnych na danym terenie. Jest to również kwestia wizerunku i marki instytucji, strategii promocyjnych miast, atrakcyjności turystycznej, jak również związanych z powstaniem nowych obiektów działań o charakterze tożsamościowego oddziaływania na mieszkańców lokalnych wspólnot.

Bez cienia wątpliwości można stwierdzić, że Polska przez ostatnie kilkanaście lat była jednym z największych „placów budowy” siedzib instytucji kultury w Europie. Pewną ilustracją tego fenomenu mogą być poglądowe dane liczbowe ${ }^{1}$. W latach 2007-2019 przybyło w Polsce 236 muzeów i oddziałów muzealnych, w latach 2009-2019 liczba miejsc o charakterze lokalnych domów kultury - centrów kultury, domów kultury, ośrodków kultury, klubów i świetlic - wzrosła o 228 podmiotów publicznych ${ }^{2}$. Polska wzbogaciła się również w ostatniej dekadzie o kilkanaście całkowicie nowych sal koncertowych, czyli projektów wymagających specjalistycznych działań architektonicznych, wiedzy i wyobraźni akustycznej. Takie zaawansowane technologicznie budynki powstały m.in. w Katowicach, Wrocławiu, Gorzowie Wielkopolskim, Lusławicach, Szczecinie, Toruniu, Kielcach, Białymstoku, Gdańsku,

1 Z zastrzeżeniem, że dane te dotyczą nie zawsze nowej infrastruktury, lecz częściowo przekształceń instytucjonalnych w ramach istniejących siedzib. Ponadto należy zastrzec, że zebrane dane dostępne są za różne okresy w zestawieniu dla muzeów oraz w zestawieniu dla domów kultury.

2 Główny Urząd Statystyczny, Działalność muzeów w 2019 roku, GUS 2020, https://stat.gov. pl/obszary-tematyczne/kultura-turystyka-sport/kultura/dzialalnosc-muzeow-w-2019-roku,12,3. html [odczyt: 15.02.2021]; Główny Urząd Statystyczny, Działalność centrów kultury, domów kultury, ośrodków kultury, klubów i świetlic w 2019 roku, GUS 2020, https://stat.gov.pl/obszary-tematyczne/ kultura-turystyka-sport/kultura/dzialalnosc-centrow-kultury-domow-kultury-osrodkow-kulturyklubow-i-swietlic-w-2019-roku,9,3.html [odczyt: 15.02.2021]; Główny Urząd Statystyczny, Instytucje kultury w 2008 r., GUS 2009, https://stat.gov.pl/obszary-tematyczne/kultura-turystyka-sport/kultura/ instytucje-kultury-w-2008-roku,5,1.html [odczyt: 15.02.2021]; Główny Urząd Statystyczny, Instytucje kultury w Polsce w 2009 roku, GUS 2010, s. 65, https://stat.gov.pl/obszary-tematyczne/kultura-turystykasport/kultura/instytucje-kultury-w-polsce-w-2009-roku,4,1.html [odczyt: 15.02.2021]. 
Wejherowie, Krakowie, Opolu, Bielsku-Białej, Lublinie, Olsztynie ${ }^{3}$. Ministrowie kultury i dziedzictwa narodowego kolejnych rządów chętnie przywołują dane na temat kluczowych inwestycji podejmowanych w ostatnich latach, dotyczy to przede wszystkim instytucji muzealnych ${ }^{4}$. Włodarze wielu polskich miast oraz marszałkowie województw realizują i planują kolejne inwestycje infrastrukturalne, muzea, teatry, sale koncertowe oraz inne obiekty o funkcji kulturalnej.

Ten fenomen zachęca do sformułowania kilku zasadniczych pytań o jego relację do wybranych wartości z zakresu celów zrównoważonego rozwoju, zwłaszcza tych dotyczących wymiarów społecznego i ekonomicznego, związanych m.in. z zakorzenieniem nowych miejsc aktywności kulturalnej w społeczności lokalnej, spójności z jej funkcjonowaniem, a docelowo również wpływu działania nowych lokalizacji kulturalnych na środowisko naturalne. Czy nowe inwestycje w kulturze to szanse, wyzwania, czy może również zagrożenia związane z przeskalowaniem, zaburzeniem równowagi lokalnych ekosystemów kultury? W jaki sposób nowe siedziby instytucji kultury zmieniają postawy, zachowania mieszkańców, ich postrzeganie przestrzeni, w której ulokowano nowy obiekt kulturalny? Co wynika z zaistnienia tych nowych budynków i miejsc dla ich użytkowników, publiczności, pracowników, liderów instytucji, konkurentów i partnerów tych instytucji, samorządów, jednostek, organizacji społecznych i wspólnot lokalnych? Jak trwały jest entuzjazm związany z tworzeniem nowego miejsca? Jak odnajdują się liderki i liderzy instytucji w realiach kolejnych lat zmagania się z utrzymaniem obiektu kulturalnego?

Zespół pod kierownictwem autora tej publikacji sformułował te pytania kilka lat temu, inicjując projekt badawczy dotyczący lokowania nowych instytucji w miejskich ekosystemach kultury w Polsce na przykładzie ośmiu instytucji w ośmiu miastach Polski. Pełne wyniki tych badań przedstawiono w raporcie ${ }^{5}$, a część z nich również $\mathrm{w}$ publikacji w języku angielskim dotyczącej infrastruktury kulturalnej w miastach i subsydiarności [Poprawski 2019]. Tekst stanowi zaktualizowaną i uzupełnioną

3 https://www.dwutygodnik.com/artykul/6669-macie-budynki-co-dalej.html [odczyt: 15.02.2021).

4 Jedno ze źródeł informacji na ten temat to strona internetowa MKDNiS, na której resort kultury informuje o liście 45 nowych muzealnych projektów inwestycyjnych oddanych do użytku od roku 2015 lub planowanych do zrealizowania do 2023 roku. Na liście tej jest co najmniej 30 całkowicie nowych obiektów, https://www.gov.pl/web/kulturaisport/inwestycje-muzealne-nasze-wiano-na-100lecie-odzyskania-niepodleglosci; https://www.gov.pl/web/kulturaisport/inwestycje [odczyt: 15.02.2021]

5 Regionalne Obserwatorium Kultury UAM, Związek Miast Polskich, Nowe lokowanie instytucji publicznych w miejskich ekosystemach kultury, ZMP, UAM 2017, https://www.miasta.pl/uploads/ attachment/file/1209/Nowe_lokowanie_instytucji_publicznych_w_miejskich_ekosystemach_kultury_w_ Polsce_2016___RAPORT_PDF_.pdf [odczyt: 15.02.2021], projekt badawczy Związku Miast Polskich, dofinansowany w ramach programu MKiDN Obserwatorium kultury, realizowany przez zespół ROK Regionalnego Obserwatorium Kultury UAM w składzie: Marcin Poprawski, Michał Mękarski, Anna Weronika Brzezińska, Marek Chojnacki, Piotr Landsberg, Przemysław Kieliszewski, Piotr Firych, Magdalena Brodniewicz, Alicja Jakubowska, Roksana Kędzierska, Klaudia Zielińska. 
wersję wcześniejszych opracowań, przegląd wybranych problemów związanych z procesem zakorzeniania nowych obiektów w lokalnych ekosystemach kultury.

\section{Tlo teoretyczne}

Badania omawiane w tym artykule dotyczą wybranych instytucji kultury funkcjonujących w ośmiu polskich miastach, ale de facto stanowią również test dla stosowania wybranych pojęć o charakterze metafor zaczerpniętych z języka ekologii. Pierwsza $z$ nich to zakorzenianie - jako środek do opisu procesów aktywowanych przez instytucje kultury, jak również względem instytucji kultury. Druga to ekosystem - pojęcie, które służy zebraniu wielu złożonych aktywności podejmowanych w dziedzinie kultury oraz ich współegzystujących sprawców, którzy działają w bardziej lub mniej sformalizowanych warunkach. Perspektywa teoretyczna, która może porządkować myślenie o tych obszarach, za pojęcie kluczowe przyjmuje kulturalny ekosystem [Holden 2015, s. 5-12; Markussen 2011, s. 8-9], ze szczególnym jego uwzględnieniem dla opisu zjawisk w lokalnych wspólnotach miejskich. W założeniu autora artykułu taki termin dobrze służy zrozumieniu relacji, które zachodzą w związku z ukorzenianiem nowego obiektu kulturalnego na danym terenie. Pomaga zrozumieć tło i zakres interakcji instytucji i jej obiektu z mieszkańcami wspólnoty lokalnej. Wzmacnia również interpretację wielu zakresów wzajemnego oddziaływania instytucji kultury i jej miejskiego otoczenia. Dlatego jeśli interesują nas bardziej społeczne i kulturotwórcze niż jedynie ekonomiczne aspekty powstawania i działania nowych instytucji oraz ich budynków, pewnie słuszniej używać metafory „zakorzeniania”, wrastania instytucji w tkankę miasta. To rozwiązanie wydaje się bliższe istocie koncepcji ekosystemowego myślenia o kulturze.

Według tez Johna Holdena realia kultury jako sfery bardzo złożonej i dynamicznej nie mieszczą się w logice procesów, liczb i trendów opisywanych przez ekonomistów, polityków czy ekspertów z obszaru polityki kulturalnej oraz zarządzania w kulturze. Kultura jest bardziej organizmem niż mechanizmem i dla jej adekwatnego do realiów opisu potrzebujemy częściej metafor ekologicznych, biologicznych, organicznych, niż technicznych. Metafora ekosystemu kultury pomaga lepiej zrozumieć naturę relacji zachodzących pomiędzy organizmami kulturalnymi, co w polskim kontekście pojmowane jest najczęściej, choć nie całkiem trafnie, jako relacje instytucji kultury i ich społecznego otoczenia.

Trudno zaprzeczyć, że metafory ekologiczne doskonale adaptują się do zagadnień polityki kulturalnej i zarządzania w kulturze. Szczególnie istotne są lokalne ekosystemy kulturalne. Wśród polskich miast różnej wielkości relatywnie niewiele posiada klarownie i wprost zarysowane ramy polityki kulturalnej, jasno wyrażone strategie na rzecz kultury. Wszelako w każdym z miast w Polsce odnajdziemy lokalne ekosystemy kultury, zamieszkane przez podmioty i organizacje publiczne, społeczne, 
przedsiębiorców, niezależnych twórców i organizatorów aktywności w obszarze kultury i dziedzictwa kulturowego. W tych ekosystemach odbywa się bardziej lub mniej złożona cyrkulacja treści, wartości i działań charakterystycznych dla uczestnictwa w kulturze, działalności twórczej oraz inicjatyw dbających o dziedzictwo kulturowe.

W tym sensie pojęcie ekosystemów kulturalnych może być postrzegane jako znacznie szersze znaczeniowo od polityki kulturalnej, jak również zarządzania w kulturze. Możemy w nim zmieścić wszelkie, te mniej i te bardziej sprofesjonalizowane, przejawy i procesy działalności związanej z kulturą. Podejście ekologiczne, czy to w obszarze diagnoz, czy podejmowania decyzji dotyczących aktywności kulturalnej, wymaga zrozumienia i oceny zestawu wielokierunkowych relacji pomiędzy różnego typu podmiotami i osobami zaangażowanymi w każdym środowisku lokalnym w proponowanie działań i rozwiązań z zakresu kultury. Dotyczy to w szczególności kształtowania miejsc, które stanowią dla osób zamieszkujących dany teren znaczące punkty odniesienia na kulturalnej mapie ich wspólnoty lokalnej. W procesach, które podlegają analizie stanu lokalnego ekosystemu kulturalnego, powinny znaleźć się zarówno te dotyczące oferty programowej, jakości dostępu do tej oferty, jak i te związane z warunkami finansowymi i lokalowo-przestrzennymi. Przegląd ekosystemów kulturalnych dotyczyć powinien również warunków pracy i rozwoju dla twórców i organizatorów życia kulturalnego, jak też ochrony i kultywowania dziedzictwa. Istotne w tej perspektywie jest zapewnianie przestrzeni nie tylko dla „starych” i zasłużonych organizacji i podmiotów, ale również dla nowych organizacji oraz tych, które zmieniają swoją przestrzeń i aktualizują ofertę na potrzeby kolejnych pokoleń mieszkańców danego terenu. Te procesy stanową przedmiot uwagi tych badaczy, którzy nie posługują się wprost metaforą ekosystemu, ale poszukują odpowiednich pojęć i teorii służących uchwyceniu fenomenów planowania i zakorzeniania nowych obiektów i instytucji kultury [Landry, Bianchini 1995; Bianchini 1996; McGuigan, 1996, 2010: 39-57; Silver, Nichols Clark 2016].

Koncepcja kulturalnego ekosystemu jest dla autora tekstu ramą formalną dla konkretyzacji zagadnień związanych z wartościami zrównoważonego rozwoju. Jej uaktywnienie w okolicznościach opracowania zagadnienia lokowania instytucji kultury w środowiskach lokalnych ma jednak sens wyłącznie w powiązaniu z szerszym kontekstem teoretycznym, który uwzględnia wielowymiarowe rozumienie kultury w relacji do wartości celów zrównoważonego rozwoju, w tym zwłaszcza kwestii zakorzenienia instytucji kultury w środowiskach lokalnych, z uwzględnieniem wielu głosów obecnych w debacie akademickiej [Soini, Dessein 2016; Kagan et al. 2018; Raj Isar 2016; De Beukelaer, Duxbury, Kangas 2017; Vandenbroeck 2017; Throsby 2017]. 


\section{Zakres i przedmiot badania}

Zespół badaczy Regionalnego Obserwatorium Kultury UAM w Poznaniu w ramach projektu realizowanego przez Związek Miast Polskich przeprowadził badania jakościowe i ilościowe w ośmiu wybranych instytucjach: Gdańskim Teatrze Szekspirowskim, Muzeum Śląskim w Katowicach, Bramie Poznania ICHOT, Centrum Dialogu im. Marka Edelmana w Łodzi, Bibliotece „Stacja Kultura” w Rumi, Filharmonii Gorzowskiej, Centrum Kultury w Grodzisku Mazowieckim oraz Centrum Kultury Browar B. we Włocławku' ${ }^{6}$. Wśród ośmiu wymiarów analizy znalazły się: (a) geneza inwestycji; (b) powstawanie obiektu w kontekście istniejącego kulturalnego ekosystemu w mieście; (c) percepcja wartości estetycznej oraz funkcjonalności nowego budynku; (d) budowanie relacji nowego „miejsca” z sąsiadami, społecznością lokalną; (e) wizerunek i społeczny odbiór nowego obiektu; (f) interakcja nowego organizmu z innymi organizacjami w miejskim ekosystemie kultury; (g) kształtowanie kultur organizacyjnych - relacji wewnątrz nowych organizacji; (h) potencjał dalszego rozwoju nowego miejsca dla aktywności kulturalnej.

Cztery z instytucji, które znalazły się wśród badanych, to marki instytucjonalne stworzone niemal „od zera”, formalnie, jako instytucje publiczne - całkiem nowi „mieszkańcy” kulturalnych ekosystemów swoich miast. Gdański Teatr Szekspirowski jest znakomitym przykładem instytucji kultury, dla której punktem wyjścia była wieloletnia działalność organizacji pozarządowej, tworzącej unikatowy międzynarodowy festiwal poświęcony twórczości Szekspira. Jej zespół wraz ze swoim charyzmatycznym liderem stał się sercem nowej instytucji miejskiej, grupą osób, której samorząd powierzył zadanie dbania o powstanie i prowadzenie bieżącej działalności nowego podmiotu. To - de facto - pierwszy po ponad 40 latach całkowicie od podstaw zbudowany obiekt teatralny w Polsce, $7935 \mathrm{~m}^{2}$ powierzchni zwieńczonych otwieranym mechanicznie dachem widowni, budynek wyposażony w scenę o bardzo zaawansowanej technologii, umożliwiającej adaptację przestrzeni scenicznej i widowni w wielu konfiguracjach. Jednocześnie to teatr bez stałego zespołu aktorskiego. Teatr wznoszono od 2011 do 2014 roku kosztem ponad $98 \mathrm{mln}$ zł, a budowę nadzorowała specjalnie w tym celu utworzona przez Miasto Gdańsk instytucja.

6 W tym samym czasie, równolegle z projektem ROK UAM i ZMP o lokowaniu nowych instytucji, prowadzony był projekt badawczy, również współfinansowany z programu Obserwatorium Kultury MKiDN - „Efekt Bilbao czy kult Cargo? Nowe instytucje kultury jako aktywatory życia społecznego, kulturalnego oraz gospodarczego", prowadzony przez Elbląskie Towarzystwo Naukowe im. Jana Myliusa oraz Instytut Socjologii Uniwersytetu Mikołaja Kopernika w Toruniu, w ramach którego pogłębionej analizie poddano trzy inne nowe instytucje kultury: Filharmonię im. Mieczysława Karłowicza w Szczecinie, Wejherowskie Centrum Kultury - Filharmonię Kaszubską oraz Operę i Filharmonię Podlaską w Białymstoku. Źródło informacji o projekcie: http://bilbao.bibel.pl/ [odczyt 15.02.2021] oraz Afeltowicz i in. 2018. 
Filharmonia Gorzowska, usytuowana w mieście zamieszkiwanym przez ok. 100000 mieszkańców, powstawała w latach 2008-2011. Miała być częścią większego kompleksu budynków centrum edukacji artystycznej związanego z muzyką, służącego kształceniu utalentowanej muzycznie młodzieży. Ostatecznie powstał główny budynek filharmonii - z salą koncertową, salą kameralną, podziemnym parkingiem oraz wieloma pomieszczeniami służącymi publiczności, muzykom i pracownikom administracji. Obiekt o powierzchni $6589 \mathrm{~m}^{2}$ jest siedzibą nowej instytucji kultury, dla której organizatorem jest Miasto Gorzów Wielkopolski. Wzniesiony został kosztem $138 \mathrm{mln}$ zł.

Trzeci przykład miejsca poddanego badaniu to Brama Poznania ICHOT pierwsze w Polsce centrum interpretacji dziedzictwa, wzniesione na poznańskiej Śródce, w sąsiedztwie i w połączeniu (poprzez przeszkloną kładkę nad rzeką) z wyspą katedralną. Miejsce to łączy cele z obszaru turystyki kulturowej oraz edukacji w obszarze dziedzictwa kulturowego związanego z najwcześniejszą historią Poznania. Narzędzia cyfrowe i narracja ukierunkowana na konkretne grupy gości są tu zasadniczymi elementami komunikacji. Formalnie rzecz ujmując, obiekt powstał jako część istniejącej instytucji Centrum Turystyki Kulturowej TRAKT, podległej Miastu Poznań, wszelako rozmach i funkcjonalność obiektu uczyniła z niego nowe serce całej instytucji ${ }^{7}$. Budynek o powierzchni $5070 \mathrm{~m}^{2}$ powstał w latach 2010-2014 za ponad $88 \mathrm{mln}$ zł.

Jedną z nowych instytucji kultury poddanych badaniu było również Centrum Kultury Browar B. we Włocławku, które powstało w latach 2012-2014 w wyniku rewitalizacji starego budynku browaru w centrum miasta, w sąsiedztwie rzeki Wisły. Oddanie do użytku $7000 \mathrm{~m}^{2}$ powierzchni kosztowało ponad $34 \mathrm{mln}$ zł. Realnie nowa instytucja powstała w wyniku połączenia zespołów dwóch wcześniej istniejących miejskich domów kultury.

Cztery pozostałe studia przypadków to relokacje siedzib instytucji do nowych budynków, względnie, w jednym przypadku, powołanie nowego oddziału instytucji w nowo zaaranżowanej przestrzeni budynku dworca kolejowego. Spośród nich najbardziej imponujące rozmiarem i skalą jest Muzeum Śląskie w Katowicach, instytucja, dla której organizatorem jest Samorząd Województwa Śląskiego, zlokalizowana w przestrzeni miasta nazywanej dziś Strefą Kultury. Tę część miasta współdzielą także inne ikoniczne instytucje: siedziba orkiestry NOSPR - z akustycznie i wizualnie zjawiskową salą koncertową, oraz Międzynarodowe Centrum Kongresowe wraz ze Spodkiem. Przeprowadzka muzeum pod nowy adres związana była zarówno z rewitalizacją terenu oraz zabytkowej części budynków byłej kopalni węgla kamiennego, jak i z powstaniem całkiem nowego obiektu wkomponowanego w teren jako część podziemna i naziemna. Łączna powierzchnia budynków na sporej

Od 1 stycznia 2021 roku Brama Poznania jest częścią Poznańskiego Centrum Dziedzictwa nowej instytucji kultury przekształconej z CTK TRAKT. 
działce pokopalnianej sąsiadującej - z jednej strony - z osiedlami mieszkaniowymi na katowickich Bogucicach oraz z centrum miasta - z drugiej strony, to $25000 \mathrm{~m}^{2}$. Z siedmiu pięter nowej budowli, tworzonej w latach 2011-2015, trzy znajdują się pod ziemią. Przestrzeń podziemna mieści m.in. ekspozycję bardzo cennej kolekcji muzeum sztuki, narracyjną wystawę stałą poświęconą historii Śląska, kolekcję związaną z dziełami scenografii, przestrzeń na wystawy czasowe. Na oddanie do użytku tej części projektu Muzeum Śląskiego wydano ponad $285 \mathrm{mln}$ zł. W kolejnych latach podejmowano dalsze działania rewitalizacyjne na muzealnej działce.

Kolejny przykład nowego obiektu to siedziba Centrum Dialogu im. Marka Edelmana w Łodzi. Budynek o powierzchni $1440 \mathrm{~m}^{2}$ powstał w latach 2008-2014 kosztem 18 mln zł. Postawiono go w sąsiedztwie blokowej zabudowy osiedli mieszkaniowych i parku miejskiego. Stanowi miejsce o hybrydowych funkcjach instytucji kultury - częściowo pokrewnych centrum kultury, a częściowo instytucji dziedzictwa. Jest miejscem związanym z pamięcią o wielokulturowej Łodzi i jej mieszkańcach. Powstało ze środków samorządowych, państwowych i prywatnych.

Centrum Kultury w Grodzisku Mazowieckim znalazło się w badaniu jako instytucja, która zadbała o nową przestrzeń dla swojej działalności. Powstanie budyn-

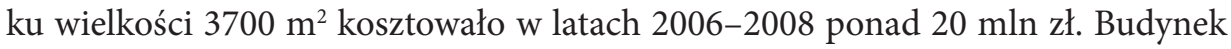
pomieścił liczne udogodnienia dla polepszenia warunków pracy instytucji w kilku obszarach, wzmocnił działalność kina, studia radiowego, lokalnego wydawnictwa medialnego.

Ostatnie studium przypadku to Stacja Kultura, nowa siedziba główna Biblioteki Publicznej w Rumi. Projekt inwestycyjny zrealizowany w latach 2013-2014, kosztujący prawie $6 \mathrm{mln}$ zł, dotyczył adaptacji budynku stacji Szybkiej Kolei Trójmiejskiej na potrzeby biblioteki. Przeznaczenie $1150 \mathrm{~m}^{2}$ tego miejsca na cele kulturalne i społeczne (również dla organizacji pozarządowych) i oddanie go lokalnej bibliotece zdobyło uznanie międzynarodowych ekspertów, którzy w roku 2016 przyznali budynkowi The Library Interior Design Award.

Zespół badaczy zainspirowany koncepcją ekosystemów kultury [Holden 2015] postanowił przyjrzeć się kilku zakresom relacji wytwarzanych pomiędzy nowymi instytucjami kultury oraz nowymi miejscami na mapie kulturalnej miasta a otoczeniem społeczno-ekonomicznym. Dotyczyło to zarówno strategicznych, jak i spontanicznych działań świeżo powołanych do życia organizacji lub nowych obiektów istniejących podmiotów, mających na celu ich zakorzenienie w lokalnym środowisku. Równie istotne jak zakorzenianie w lokalnej tkance społecznej i samorządowej jest również kształtowanie marki instytucji i miejsca oraz konkretne oddziaływanie na zaangażowanie, uczestnictwo, postawy i przekonania mieszkańców względem nowego obiektu. Zasadniczym wymiarem porównawczej analizy sposobu zakorzeniania się nowych bytów w lokalnych ekosystemach kultury było szczególne zwrócenie uwagi na relacje z istniejącymi już organizmami, zwłaszcza instytucjami kultury współdzielącymi ten sam lokalny obszar. Rozpoznano tu relacje współpracy 
i wsparcia, ale również współzawodnictwa. W ramach badań ujawniły się liczne potencjały, szanse i zasoby instytucji i ich otoczenia społecznego, ale też przeszkody dla zbalansowania samych instytucji oraz współdzielonych przez nie ekosystemów, tworzących warunki do współpracy i współzawodnictwa.

Wybrany model badania zakładał kilka metod diagnostycznych, takich jak: analiza danych zastanych, dokumentów, badania netograficzne i analiza dyskursu, komunikacja zapośredniczona w mediach społecznościowych, badania terenowe w instytucjach, liczebnie dominujące badania ilościowe (ankiety papierowe, ankiety elektroniczne) i badania jakościowe (badania fokusowe FGI oraz IDI - wywiady pogłębione) z udziałem pracowników, liderów instytucji, liderów instytucji i organizacji „konkurencyjnych” współdzielących ten sam kulturalny ekosystem, ekspertów z lokalnego środowiska, samorządowców oraz publiczności, użytkowników ich oferty. Zakres działań badawczych w zestawieniu liczbowym ilustruje tabela 1 .

Tabela 1. Podstawowe wskaźniki liczbowe badania

\begin{tabular}{|l|c|}
\hline \multicolumn{1}{|c|}{ Zakres } & Liczba \\
\hline Badane instytucje kultury & 8 \\
\hline Badania terenowe & 8 \\
\hline $\begin{array}{l}\text { Badania netograficzne i analizy dyskursu w mediach } \\
\text { społecznościowych }\end{array}$ & 8 \\
\hline $\begin{array}{l}\text { Indywidualne wywiady pogłębione (IDI) [z dyrektorami } \\
\text { i pracownikami badanych instytucji, dyrektorami i pracownikami } \\
\text { „starych" instytucji w badanym mieście oraz samorządowcami] }\end{array}$ & 34 \\
\hline $\begin{array}{l}\text { Osoby uczestniczące w 8 zogniskowanych wywiadach grupowych (FGI) } \\
\text { [środowisko opinio- i kulturotwórcze badanych miast] }\end{array}$ & 91 \\
\hline Ankiety z pracownikami 8 instytucji & 153 \\
\hline Ankiety z publicznością, odbiorcami oferty badanych instytucji & 434 \\
\hline Łącznie wszystkie badane osoby & 712 \\
\hline
\end{tabular}

Źródło: ROK UAM / ZMP 2017, s. 12.

\section{Wybrane wyniki badania}

Istnieje kilka szczególnie interesujących wyników badania nowych siedzib instytucji kultury, które wskazują na okoliczności i warunki ich zakorzeniania w lokalnych ekosystemach kultury. Przedmiotem odniesienia dla nowych obiektów są zawsze instytucje i miejsca dłużej funkcjonujące w środowisku lokalnym. Pierwsze dwa 
wybrane zestawienia wyników diagnozy pokazują zbiorczo odpowiedzi pracowników ośmiu badanych instytucji oraz ich publiczności. Z przeprowadzonych badań ilościowych wynika, że zarówno publiczność, jak i pracownicy nowych instytucji dość podobnie oceniają potencjał tychże instytucji. Ich zdaniem cieszą się one dużym kredytem zaufania i są w stanie z dużo większą łatwością niż tzw. stare instytucje przekonać mieszkańców do swojej oferty. Wynik ten pokazuje siłę świeżości oraz skupienie uwagi ankietowanych osób na atrakcyjności tego, co nowe w ofercie kulturalnej, na aktualizacji możliwych aktywności kulturalnych kierowanych do wspólnoty lokalnej (rys. 1).



Rys. 1. Opinia na temat tego, czy nowym instytucjom i obiektom kultury jest łatwiej/ trudniej niż starym przekonać mieszkańców do swojej oferty $(n=587)$

Źródło: ROK UAM / ZMP 2017, s. 48.

Większe zróżnicowanie między przedstawicielami pracowników i publiczności instytucji jest widoczne w odpowiedziach udzielonych na pytanie o wybaczanie błędów lub „taryfę ulgową” w ocenie nowego obiektu kulturalnego. Goście instytucji są znacznie bardziej wyrozumiali niż sami ich pracownicy. Ponad $70 \%$ badanych pracowników ma przekonanie, że ich instytucje są bardzo uważnie oceniane, a błędy lub potknięcia nie będą im łatwo wybaczane. Podobną opinię wyraża mniejszość badanej publiczności - ponad 44\% dostrzega brak taryfy ulgowej dla nowych instytucji w początku ich działalności, natomiast ponad 55\% jest gotowa nie oceniać surowo młodej organizacji i jej błędów. Ilustruje to rysunek 2. 


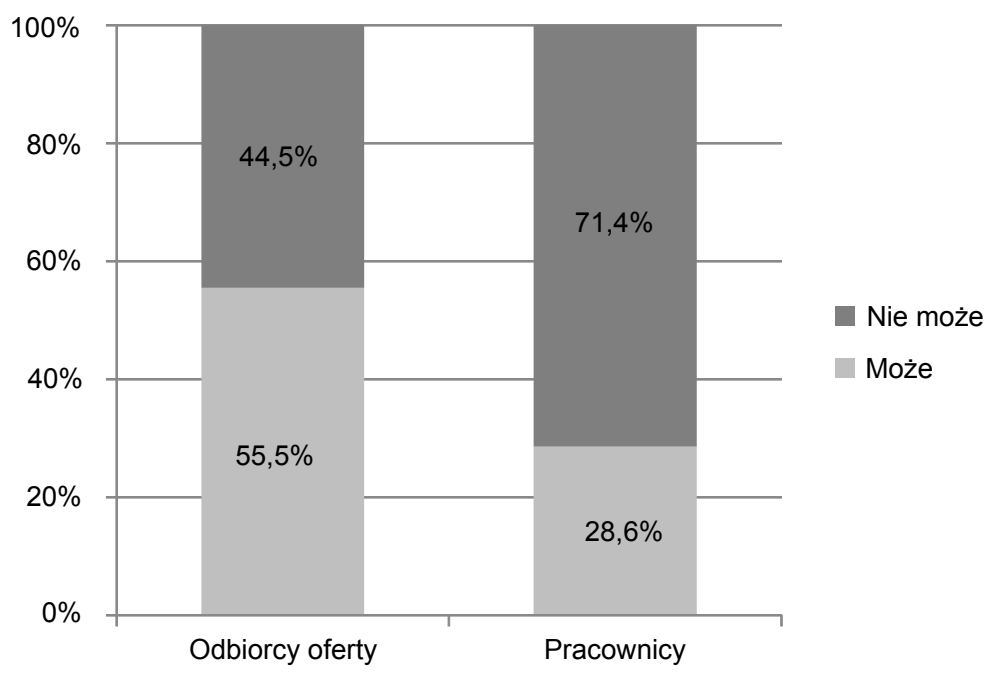

Rys 2. Opinia na temat tego, czy nowa instytucja kultury nie może/może liczyć na „taryfę ulgową" na początku swojej działalności $(n=587)$

Źródło: ROK UAM / ZMP 2017, s. 50.

Wiele refleksji budzą wyniki badania percepcji pracowników nowych miejsc kultury i ich odpowiedzi na pytanie o postrzeganie lokalnego ekosystemu kultury jako konkurencyjnego albo kooperatywnego. Widzimy tu, jak postrzegane jest nastawienie na współpracę albo na współzawodnictwo w obrębie jednego miejskiego ekosystemu jako obszaru działania starych i nowych instytucji. Rysunek 3 ilustruje rozbieżności pomiędzy sytuacjami ośmiu różnych organizacji, które odnotowaliśmy, analizując odpowiedzi pracowników nowych instytucji i obiektów. W trzech z badanych miejsc dominuje ocena otoczenia zewnętrznego jako przede wszystkim konkurencyjnego - inni współmieszkańcy lokalnego ekosystemu kulturalnego nie są postrzegani jako specjalnie otwarci na włączanie nowego podmiotu do współpracy, przychylni jego rozwojowi czy w szczególny sposób ułatwiający działania nowego organizmu. Pracownicy tylko jednej instytucji - konkretnie Muzeum Śląskiego, kierowanego jeszcze wówczas przez Alicję Knast - wskazywali w trakcie badania, że w ich ocenie działają w ekosystemie, który jest nastawiony bardzo przychylnie i ukierunkowany na współpracę. 


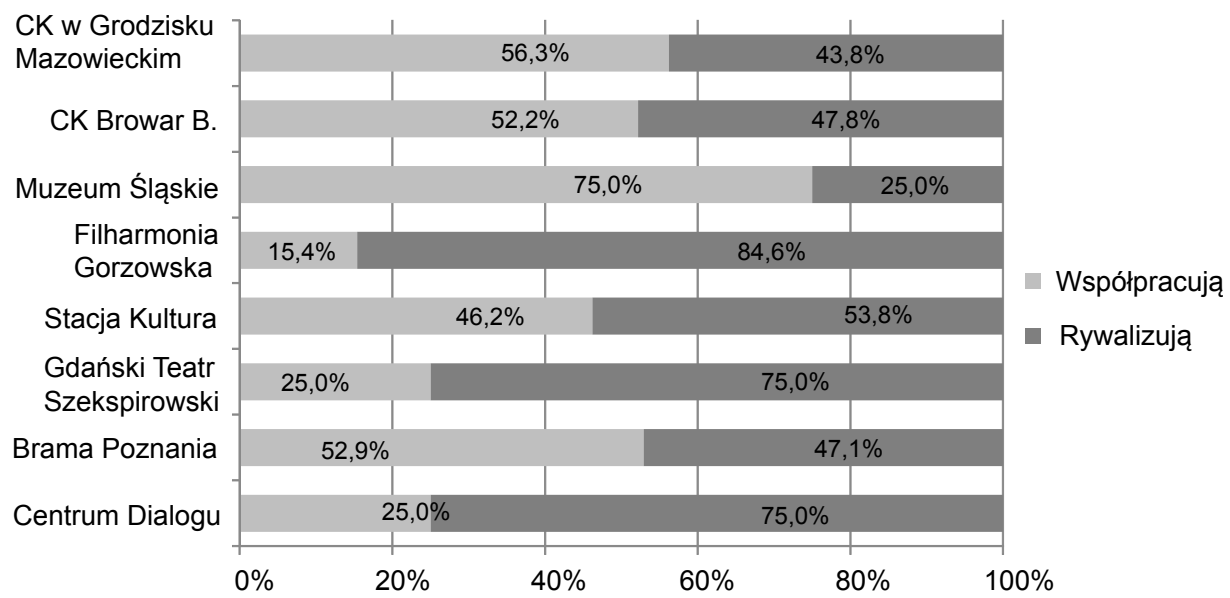

Rys. 3. Opinie na temat tego, czy stare instytucje częściej współpracują czy rywalizują z nowymi instytucjami w mieście, wyrażane przez pracowników poszczególnych instytucji $(n=153)$

Źródło: ROK UAM / ZMP 2017, s. 52.

Taki punkt widzenia na lokalne ekosystemy kulturalne jest de facto wzmocniony przez wyniki innego fragmentu badań skierowanych do pracowników nowo ulokowanych podmiotów kulturalnych, który bardziej bezpośrednio dotyczy ich interakcji ze wspólnotą lokalną. Pytanie, na które zbiorcze odpowiedzi ujęte są na rysunku 4, zachęca do wskazania zakresu odpowiedzialności nowych instytucji. Czy skuteczność zakorzeniania się nowego obiektu w lokalnym ekosystemie jest zależna od wysiłku kadry nowego podmiotu, czy też decyduje o niej w większym stopniu otwartość istniejącego ekosystemu - otoczenia, które jest bardziej lub mniej przygotowane i chętne do przyjęcia nowego organizmu do istniejącej wspólnoty. Większość badanych instytucji - poprzez swoich pracowników - wskazuje, że to ich własne instytucje są przede wszystkim odpowiedzialne za sukces lub porażkę takiego ukorzeniania nowych obiektów. Jedynie dwie z badanych instytucji widzą warunki tego procesu nieco inaczej - ich zdaniem większy ciężar odpowiedzialności za powodzenie we wrastaniu nowej instytucji w istniejący ekosystem spoczywa po stronie otoczenia. 


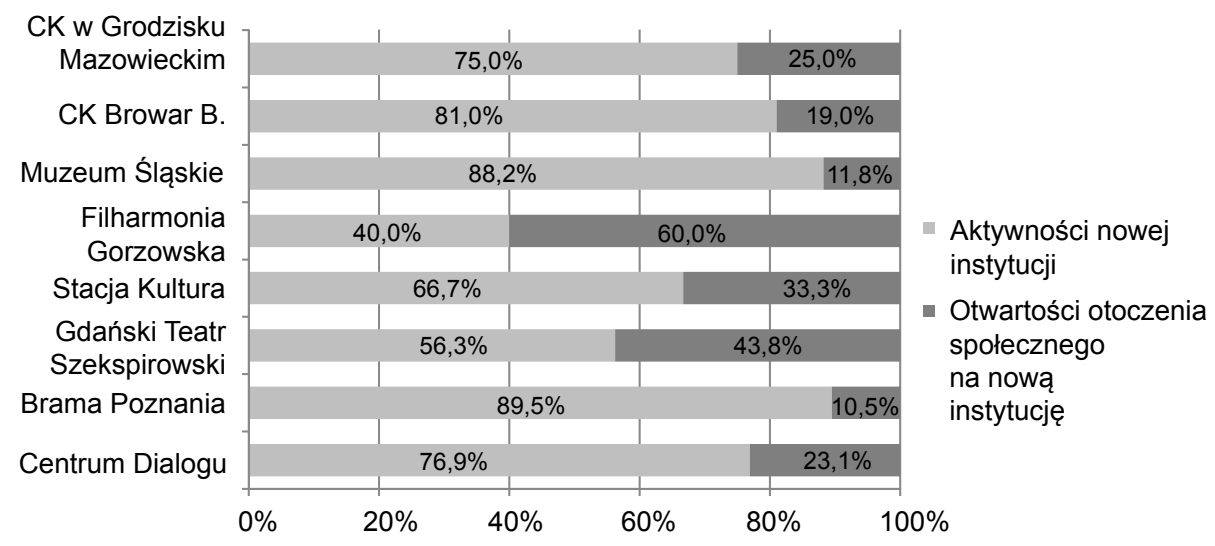

Rys. 4. Opinie na temat tego, czy skuteczność procesu „wrastania” nowych siedzib w społeczność lokalną zależy bardziej od aktywności nowej instytucji czy od otwartości otoczenia społecznego na nową instytucję, wyrażane przez pracowników poszczególnych instytucji $(n=153)$

Źródło: ROK UAM / ZMP 2017, s. 94.

Z całego zestawu wyników badania prowadzonego w ośmiu miastach warto zwrócić uwagę na jeszcze kilka obszarów diagnozowanych w nowych obiektach kulturalnych. W tym wypadku zarówno pracownicy instytucji, jak i ich odbiorcy odpowiadali na pytania dotyczące wpływu nowych miejsc na miejski ekosystem. Wśród czynników do oceny zaproponowano takie, które dotyczą tożsamości lokalnej, atrakcyjności w aspekcie promocji, wartości oraz wizerunku i społecznej recepcji nowych obiektów. Można dostrzec, że opinie i podejście do tych zagadnień ze strony tych dwóch zbiorowości respondentów są całkiem zgodne. Pierwsze z pytań zawierało prośbę o wskazanie na skali liczbowej od 1 do 5 oceny 11 tez na temat oddziaływania nowego obiektu kulturalnego. Ocena 1 oznaczała czynnik mało ważny, natomiast ocena 5 - czynnik bardzo ważny. Zbiorcze, średnie wyniki zilustrowano na rysunku 5. Wśród najwyżej ocenianych aspektów wpływu świeżych lokalizacji instytucji na lokalną społeczność znalazły się: wpływ na promocję miasta, zwiększenie oferty dostępu do aktywności kulturalnych, bycie powodem do dumy mieszkańców, pozytywny wpływ miejsca na okolicę. Aspekty, które uzyskały najwyższe oceny w percepcji zarówno kadry instytucji, jak i mieszkańców - średnia ocen tych grup ukształtowała się w identyczną hierarchię najwyżej i najniżej ocenianych oddziaływań - dotyczyły przede wszystkim wizerunku, elementów symbolicznych i tożsamościowych oraz - w jednym wypadku - praktycznych, dotyczących zwiększenia dostępności oferty. Obydwie grupy respondentów zgodnie nie zgodziły się $z$ hipotetycznym stanowiskiem, że nowe inwestycje w kulturze stanowią przedmiot 
konfliktów lokalnych oraz że ograniczają, zubażają zasób miejskich środków na kulturę. Można jedynie zaznaczyć, że sytuacja ta wygląda nieco inaczej, gdy przyjrzymy się wynikom dla poszczególnych instytucji. W jednej z instytucji - co koreluje z wynikami innych elementów badania dla tego obiektu, dotyczących akceptacji ze strony otoczenia - konfliktogenność związana z powstaniem instytucji jest oceniana jako bardziej realna (rys. 5).

Wzmacnia lokalną tożsamość mieszkańców

Przyciąga uwagę mediów i sponsorów

Pozytywnie zmienia okolicę

Stanowi powód do kłótni i lokalnych sporów

Świadczy korzystnie o władzach miasta

Zwiększa dostęp mieszkańców do oferty kulturalnej

Ogranicza ilość miejskich środków finansowych Przyciąga turystów

Przyciąga wcześniej niekorzystających Stanowi powód do dumy dla mieszkańców Promuje miasto i świadczy o jego rozwoju

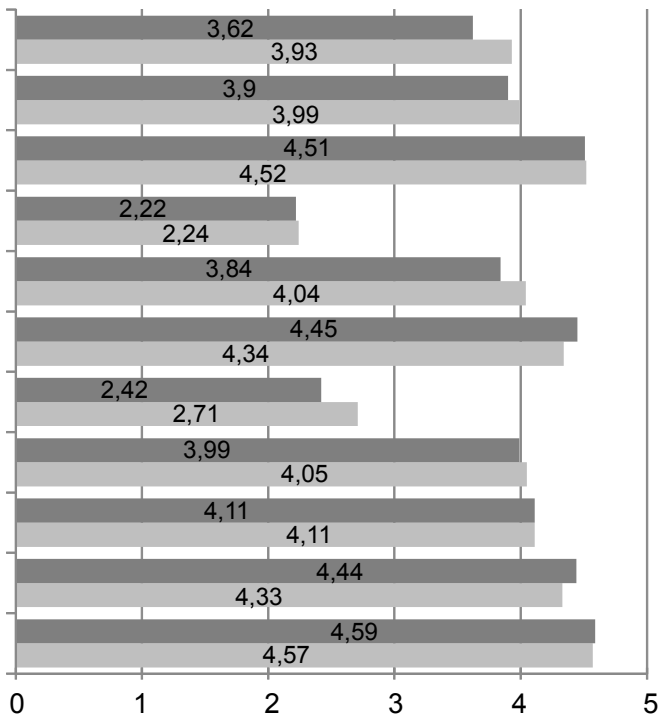

- Pracownicy Odbiorcy oferty

Rys. 5. Ocena oddziaływania nowego obiektu instytucji kultury w mieście, w którym obiekt się znajduje (średnia ocen dla skali, 1 - w bardzo małym stopniu, 5 - w bardzo dużym stopniu, z wyłączeniem wskazań 0 - nie mam zdania/wiedzy)

Źródło: ROK UAM / ZMP 2017, s. 117.

Rysunek 6 ilustruje odpowiedzi dotyczące oceny różnicy, jaka zaszła po ulokowaniu inwestycji na danym terenie miejskim. Opinie dotyczyły kolejnych 11 wymiarów możliwego wpływu obiektu na najbliższe otoczenie. Zarówno odwiedzający miejsce, jak i osoby tam pracujące wśród najważniejszych obszarów zmian, jakie zaszły za sprawą zaistnienia nowego budynku, wskazały: zmianę klimatu i stylu miejsca, zmianę walorów estetycznych miejsca oraz otwartość i przyjazność dla mieszkańców miejsc w nowym kształcie. Pracownicy bardziej doceniali trzy zakresy zmian związanych z wpływem instytucji na otoczenie, a mianowicie zwiększenie odczucia otwartości, gościnności przestrzeni, polepszenie jego reputacji oraz sprawienie, że miejsce stało się bardziej popularne, bardziej uczęszczane. Co ciekawe, choć nie stanowiło to szczytu 
hierarchii oceny, publiczność instytucji zdecydowanie bardziej doceniała zmiany w zakresie poczucia bezpieczeństwa, czystości i skomunikowania transportowego miejsca. Pracownicy zdecydowanie mniej dostrzegali poprawę w tym zakresie.

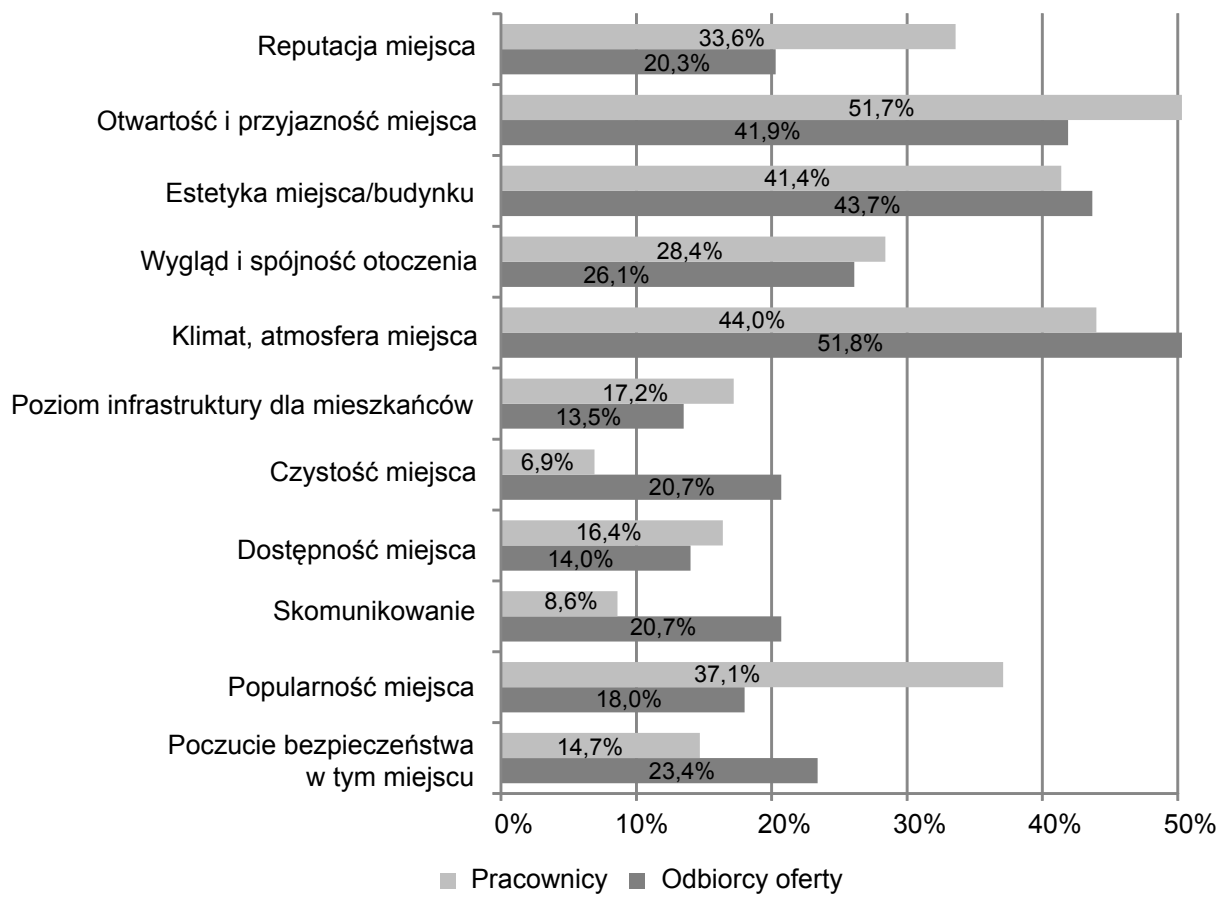

Rys. 6. Zmiany warunków panujących w badanym miejscu przed powstaniem nowego budynku i obecnie szczególnie ważne dla odbiorców oferty i pracowników. Pytanie wielokrotnego wyboru, respondent/respondentka mógł/mogła wskazać więcej niż jedną odpowiedź (maksymalnie trzy), dlatego łączne wartości procentowe wynoszą więcej niż 100\% Źródło: ROK UAM / ZMP 2017, s. 126.

\section{Rezultaty i dyskusja}

Badania przyniosły szereg wniosków związanych z zakorzenianiem się nowych siedzib instytucji kultury w lokalnych ekosystemach kulturalnych. Nowy obiekt architektoniczny daje możliwość aktywacji nowych funkcji instytucji kultury oraz partycypacyjnych i edukacyjnych praktyk służących społeczności lokalnej. Nowe miejsce kulturalne jest potencjalnie doskonałym stymulantem aktywności kulturalnej dla lokalnych mieszkańców. Przy realizacji dobrego programu zakorzeniania instytucji w społeczności lokalnej nowa lokalizacja stanowi zachętę do wizyty i bywania 
w obiekcie, również dla tych mieszkańców, którzy wcześniej nie odwiedzali instytucji kultury czy obiektów artystycznych i nie postrzegali siebie jako publiczności danej instytucji.

Nowy budynek o funkcji kulturalnej - zwłaszcza jeśli posiada wysoką jakość estetyczną i architektoniczną - może być skutecznym, choć zaledwie jednym $\mathrm{z}$ wielu narzędzi rewitalizacji dla najbliższego otoczenia instytucji, a w wypadku ikonicznych obiektów - również dla całego miasta. Warto zwrócić uwagę na to, że mieszkańcy miasta są najczęściej dumni z jakości estetycznej nowych budynków kulturalnych oraz zmian, jakie pod wpływem ich funkcjonowania zaszły w ich otoczeniu. Jest to solidny punkt wyjścia do budowania i wzmacniania procesów tożsamościowych i partycypacyjnych w relacji społeczności lokalnej i instytucji kultury. Pewnym problemem jest jednak brak wiedzy członków społeczności lokalnych na temat ich wkładu - jako podatników - w powstanie nowego obiektu oraz kosztów, które trzeba będzie ponieść dla działania instytucji. Jakość komunikacji i łatwość dostępu do informacji pozostawiają w tym względzie bardzo wiele do życzenia. Istotne jest również to, że procesy partycypacyjne prowadzone przez nowe instytucje i nowe miejsca stworzone dla istniejących instytucji są częściej spontaniczne niż zaprogramowane z wyprzedzeniem. Nie stanowią integralnej części strategii i misji instytucji, lecz funkcjonują jako projekty wynikające $\mathrm{z}$ bieżących pomysłów konkretnych osób zatrudnionych $\mathrm{w}$ instytucjach.

Problemem jest również to, że w historii powstawania nowych obiektów kulturalnych wyraźnie widać brak dbałości o bardzo dobrą jakość i skuteczność komunikacji z pozostałymi podmiotami ekosystemu, innymi instytucjami kultury, organizacjami kulturalnymi. Te zaniedbania powodują niezamierzoną presję konkurencyjności między podmiotami i nie budują systemu zachęty do współpracy z nowo zaistniałą instytucją lub nowym obiektem. Część instytucji, siłą osobowości ich liderek i liderów, stwarza wiele szans do obopólnie korzystnej współpracy i zabiega o nią, traktując działania wspólne jako rozwój własnej organizacji. Niestety spora część instytucji „zamieszkujących” wspólny ekosystem widzi w nowym organizmie jedynie konkurenta, względem którego zalecana jest co najwyżej obojętność. W przypadku źle zaprogramowanych nowych instytucji kultury - złego planowania w aspekcie misji, budowania relacji z istniejącym ekosystemem kulturalnym, komunikacji, prowadzenia procesów zarządzania oraz metod finansowania - istnieje bardzo realne ryzyko, że nowa instytucja, nowa inwestycja infrastrukturalna w obszarze organizacji kultury doprowadzi do obniżenia budżetowych „wód gruntowych” pod innymi istniejącymi już instytucjami i organizacjami, które dzielą wspólny miejski ekosystem kulturalny i wspólny zasób budżetu samorządowego.

Przed wybudowaniem instytucji w istniejącym już ekosystemie podmiotów kulturalnych, zwłaszcza tych zlokalizowanych w sąsiedztwie budowanej nowej instytucji, trzeba bardzo precyzyjnie określić rolę i warunki rozwoju instytucji w kontekście jej istniejącego już otoczenia - kto jest gotów być partnerem, a kto będzie godnym konkurentem. W zasadzie należy tu pomyśleć o studium przyszłej koegzystencji 
miejsca i konsekwencji ulokowania instytucji i jej wpływu na otoczenie - rozumiane we wszystkich zakresach zrównoważonego rozwoju. Analiza relacji nowego organizmu z istniejącym ekosystemem i próba zobaczenia możliwej zmiany, jaka zajdzie na skutek zakorzeniania nowego obiektu, udzieliłaby odpowiedzi na wiele wątpliwości i przypuszczeń oraz zweryfikowałaby wstępne założenia osób planujących. Inwestując w nowe obiekty, nie można zaniedbać tych „starych”, ciągle obecnych i rozwijających się. Zakorzenianie nowych obiektów musi być powiązane z kultywacją tego, co już istnieje. Instytucje funkcjonujące od lat w miejskim ekosystemie kultury muszą mieć przekonanie, że koszt, jaki poniosą przy okazji powstawania nowej instytucji, będzie uwzględniał ich rozwój. Również mieszkańcy nie powinni mieć odczucia, że buduje się nowe kosztem starego. Należy zadbać o skuteczną i klarowną dla wszystkich uczestników procesu komunikację społeczną. Ponadto organizator instytucji powinien niwelować różnice powstałe między nową instytucją a pozostałymi instytucjami kultury. Pomiędzy częścią badanych instytucji a pozostałymi organizacjami kulturalnymi, dla których miasto jest organizatorem, widać wyraźną przepaść infrastrukturalną. Łączy je to, że każda na swój sposób podejmuje wysiłek zaspokajania potrzeb kulturalnych różnych grup społecznych. Istnieją takie instytucje, które wymagają natychmiastowej interwencji finansowej, a brak perspektyw zmiany złej sytuacji budzi frustrację i niechęć do nowej instytucji, o którą samorząd szczególnie dba.

Zmiana czy ufundowanie nowej instytucji, która wprowadza całkowicie nowe standardy myślenia, nową jakość, widoczność, prestiż danej dziedziny kultury (np. poprzez nowoczesne, ikoniczne muzeum lub teatr) powinna promieniować na inne instytucje tego typu w mieście lub regionie. Służyć temu może sieciowanie tego typu instytucji, dzielenie się doświadczeniami, uczenie innowacyjnych rozwiązań, upowszechnianie nowych metod działania. Istotne jest również zacieśnianie współpracy nowo lokowanej instytucji z innymi instytucjami i organizacjami w mieście. W niektórych z badanych obiektów widoczne są przykłady systemowych rozwiązań stymulujących współpracę w lokalnym ekosystemie kultury.

Wyniki badania skłaniają do obserwacji, że niezwykle istotne jest „szycie instytucji” na miarę realnych, roztropnie ocenionych, zbalansowanych możliwości lokalnego ekosystemu. Ważne jest, by działania związane z nowym miejscem dla kultury szanowały i dbały o zasoby otoczenia nowej inwestycji, środowiska zarówno społecznego, materialnego, ekonomicznego, jak i naturalnego. Należy pamiętać o odpowiednim zabezpieczeniu finansowym instytucji w perspektywie wieloletniej. Część badanych instytucji zmaga się z trudną sytuacją budżetową wynikającą z niewłaściwie, niekiedy wręcz nieroztropnie, budowanych prognoz oddziaływania powstającej instytucji na finanse publiczne. Doprowadza to nie tylko do kryzysu wewnątrz instytucji i samorządu, ale bywa także istotnym powodem niezadowolenia mieszkańców (są oni niezadowoleni z faktu, że instytucja powstała w wyniku okrojenia szerszego planu inwestycyjnego) oraz innych placówek publicznych w mieście 
(w budżecie lokalnym brakuje środków na dobre funkcjonowanie pozostałych instytucji). Nowo powstające instytucje i obiekty nie powinny nadużywać wskaźnikowania, które może okazać się przeszacowane, jeśli nie zostało oparte na rzetelnych badaniach społecznych i rynkowych. Pozwoli to uniknąć niepotrzebnych perturbacji i tzw. szukania dawców wskaźników - podmiotów, projektów, wydarzeń, których instytucja nie chce realizować, które nie pasują do jej linii programowej i tożsamości - ale zapewniają frekwencję lub zapewniają liczbę wydarzeń przewidzianą w planie. Warto natomiast - z myślą o zbalansowanym ekosystemie spędzania czasu przez mieszkańców - podjąć w sposób strategiczny wyzwania harmonizacji działalności instytucji kultury z ofertą powiązaną z obszarami rekreacji i dobrostanu zdrowotnego.

Wyniki badania ośmiu przykładowych nowych obiektów kulturalnych ujawniają wagę kilkunastu zasadniczych wymiarów aktywności instytucji kultury oraz ich samorządowych organizatorów, które pozwalają im mocniej „zakorzenić się” w miejskim ekosystemie kultury. Nowy budynek otwiera zupełnie nowe możliwości. Poprawia warunki funkcjonowania placówek i otwiera instytucje na nowe elementy działalności, które nie były dotąd możliwe lub były utrudnione w starszych, niedostosowanych i niekomfortowych przestrzeniach (m.in. dostępność dla osób z niepełnosprawnością, bogatsza i bardziej różnorodna oferta, spełnianie warunków technicznych dla uruchomienia nowych form działalności). Nowo zakorzeniane instytucje kultury nie powinny zamykać się w bryle architektonicznej, lecz rozwijać działalność w otoczeniu swojej siedziby, docierając do społeczności, tworząc w niej kręgi uczestników świadomych misji i celów instytucji.

\section{Bibliografia}

Afeltowicz Ł., Gadecki J., Olechnicki K., Szlendak T., Wróblewski M. (2018), Efekt Bilbao/kult Cargo. Nowe instytucje kultury w Polsce, Elbląg: Wilk Stepowy.

Bianchini F. (1996), Cultural planning: An innovative approach to urban development, [w:] J. Verwijnen, P. Lehtovuori (red.), Managing urban change, Helsinki: University of Art and Design Helsinki, s. 18-25.

De Beukelaer Ch., Duxbury N., Kangas A. (2017), Cultural policies for sustainable development: four strategic paths, „International Journal of Cultural Policy”, t. 23, nr 2, s. 214-230.

Holden, J. (2015), The ecology of culture, AHRC, https://ahrc.ukri.org/documents/project-reports-and-reviews/the-ecology-of-culture [odczyt: 15.02.2021].

Isar Y.R. (2016), 'Culture', 'sustainable development' and cultural policy: a contrarian view, „International Journal of Cultural Policy", 23, 2, s. 148-158.

Kagan S., Hauerwaas A., Holz V., Wedler P. (2018), Culture in sustainable urban development: Practices and policies for spaces of possibility and institutional innovations, „City, Culture, and Society", vol. 13, s. 32-45.

Landry Ch., Bianchini F. (1995), The creative city, London: Demos. 
Markussen A. et al. (2011), California's arts and cultural ecology, James Irvine Foundation www. irvine.org/publications-by-topic/arts/arts-ecology-reports [odczyt: 15.02.2021].

Maughan C., Bianchini F. (2004), Economic and social impact of cultural festivals in the East Midlands, Report for Arts Council England, https://static.a-n.co.uk/wp-content/uploads/2016/09/Economic-and-social-impact-final-report.pdf [odczyt: 15.02.2021].

McGuigan J. (1996), Rethinking cultural policy, Maidenhead: Oxford University Press.

McGuigan J. (2010), Cultural analysis, London: Sage.

Poprawski M. (2016), Intergenerational transmission of values and cultural sustainability: The cultural participation of local, small town communities in Poland, „Law, Social Justice and Global Development Journal”, 1, https://warwick.ac.uk/fac/soc/law/elj/lgd/2016-1/ [odczyt: 15.02.2021].

Poprawski M. (2019), New organisms in the cultural 'ecosystems' of cities: The rooting and sustainability of arts and culture organizations, [w:] W.J. Byrnes, A. Brkić (red.), The Routledge companion to arts management, London: Routledge, s. 278-295.

ROK UAM/ZMP - Regionalne Obserwatorium Kultury UAM i Związek Miast Polskich (2017), Nowe lokowanie instytucji publicznych w miejskich ekosystemach kultury, https://www.miasta. pl/uploads/attachment/file/1209/Nowe_lokowanie_instytucji_publicznych_w_miejskich_ ekosystemach_kultury_w_Polsce_2016___RAPORT_PDF_.pdf [odczyt: 15.02.2021].

Silver D.A., Nichols Clark T. (2016), Scenescapes: How qualities of place shape social life, Chicago and London: The University of Chicago Press.

Soini K., Dessein J. (2016), Culture-sustainability relation: Towards a conceptual framework, „Sustainability”, 8, s. 167; doi:10.3390/su8020167.

Throsby D. (2017), Culturally sustainable development: theoretical concept or practical policy instrument, „International Journal of Cultural Policy”, 32, 2, s. 133-147.

Vandenbroeck Ph. (2017), Culture and the social learning process towards sustainability, [w:] S. Asikainen, C. Brites, K. Plebańczyk, L. Rogač Mijatović, K. Soini (red.), Culture in sustainability. Towards a transdisciplinary approach, Jyväskylä, s. 22-28. 